Ann. Biol. anim. Bioch. Biophys., 1978, 18 (5), 1205-1221.

\title{
Functional differentiation of Leydig cells in the testis of the fetal monkey (Macaca fascicularis)
}

\author{
par J.-P. FOUQUET, D.-C. DANG *, Nicole MEUSY-DESSOLLE \\ Laboratoire de Physiologie de la Reproduction des Vertébrés, Université Paris VI, \\ 4, place Jussieu, 75230 Paris Cedex 05, France. \\ * Laborafoire d'Anatomie, U. E. R. Biomédicale, 45, rue des Saints-Pères, \\ 75006 Paris, France.
}

\begin{abstract}
Summary. The testicular interstitial tissue of Macaca fascicularis was studied by electron microscopy in 22 fetuses aged 37 to 82 days. The testis differentiated during week 6 of pregnancy. The interstitial tissue, comprised solely of mesenchymal cells, developed during week 7 (predifferentiation phase). True Leydig cells entered the differentiation phase during week 8 , forming a dense relatively homogeneous population at maximum differentiation during the maturity phase lasting about 10 days. The Leydig cells entered the involution stage at the end of week 10 ; most of these cells dedifferentiated and some degenerated. This 4-stage chronology is comparable to that described in man.

Ultrastructural differentiation of macaque Leydig cells followed the general plan observed in other species, i. e. SER development, multiplication of mitochondria with tubular cristae and accumulation of lipid droplets. These structures were associated in operational areas, maximally extended during the maturity stage. Later, the SER regressed and lipid droplets were more numerous. A good correlation was found between structural development of Leydig cells and plasma testosterone levels in the same fetuses.
\end{abstract}

\section{Introduction.}

Beginning in fetal life the Leydig cells are the main source of testicular androgen and their role in the differentiation and maintenance of the male genital tract is well known (Jost ef al., 1973). They appear early, shortly after testicular differentiation. Using electron microscope techniques, their development has been studied in man (Pelliniemi and Niemi, 1969), guinea-pig (Black and Christensen, 1969), rat (Narbaitz and Adler, 1967 ; Merchant Larios, 1976), mouse (Russo and De Rosas, 1971 ; Scheib, 1972), rabbit (Gondos and Conner, 1972), hamster (Gondos ef al., 1974) and pig (MeusyDessolle, 1972). Fetal Leydig cells have high androgenic activity (Meusy-Dessolle, 1972 ; Rigaudière, 1976) and plasma testosterone level in the fetus may reach that of the adult.

As all steroid hormone-producing cells, Leydig cells have an abundant smooth endoplasmic reticulum frequently associated with mitochondria usually possessing tubular cristae (Christensen and Gillim, 1969 ; Christensen, 1975). These criteria may be useful in determining the onset and regression of testosterone secretion during 
fetal life. This information is necessary to an understanding of the differentiation of genital routes and accessories. We have only fragmentary data on fetal plasma testosterone levels in monkey from 60 days (Resko et al., 1973). Light microscopy studies by Wagenen and Simpson (1965) suggest that this steroid may be secreted earlier.

We have tried to define the ultrastructural evolution of Leydig cells from differentiation to birth, attempting to associate the changes observed to testosterone secretion levels and to the differentiation of testicular structures and excretory ducts. This paper is limited to the first period of activity of the fetal testis of Macaca fascicularis.

\section{Material and methods.}

In our rearing conditions, Macaca fascicularis females have a regular cycle all year long. They are put with the male for 24 to $48 \mathrm{hrs}$. between days 12 and 15 of the cycle. The length of pregnancy is counted from the first day of cohabitation (Dang, 1977a).

The fetuses were taken by cesarian (Dang, 1977b). After dissection, the mesonephros-gonad was transferred to cold 1 p. 100 glutaraldehyde in $0.125 \mathrm{M}$ cacodylate buffer at $\mathrm{pH} 7.4$ for 30 to $45 \mathrm{mn}$. The increase of myelin figures during week 8 of development led us to successfully fix older fetus testes in a 1 p. 100 glutaraldehyde 1 p. 100 paraformaldehyde mixture in the same buffer. After washing $1 \mathrm{hr}$ in this buffer with $0.12 \mathrm{M}$ sucrose added, the material was post-fixed for $1 \mathrm{hr}$ in $1 \mathrm{p} .100$ $\mathrm{OsO}_{4}$ in the same buffer without sucrose. The blocks were dehydrated by acetone and embedded in Epon 812 (Luff, 1971).

The semi-thin sections were stained with toluidine blue. The thin sections were contrasted with uranyle acetate-lead citrate (Venable and Coggeshall, 1965) and observed on a JEM $100 \mathrm{~B}$.

The testes of 22 fetuses 37 to 82 days old were studied. From 57 days ombilical arterial blood was collected on the same male fetuses, but also on female fetuses to determine plasma testosterone levels. This steroid was radioimmunoassayed using the method of one of us (Meusy-Dessolle, 1974).

\section{Results.}

At day 37 of pregnancy, the gonad is still undifferentiated, but at 39 to 40 days (fig. 1) the testis is recognized with certainty because the gonad blastema is organized into anastomosed cords, separated from the germinal epithelium by a thin tunica

\section{PLATE I}

FIGS. 1,2. - General views of testis at 40 (1) and 43 (2) days of pregnancy : sex cords (sc), tunica albuginea (a) and insterstitium (i). $\times 250$.

FIG. 3. - Undifferentiated mesenchymal cells in the interstitium (i) surrounding part of a sex cord (sc) in a 46-day testis $\times 8000$. 
albuginea. Practically no interstitial tissue is seen up to 41 days ; it consists of rare mesenchymal cells surrounding tiny capillaries (fig. 1).

Week 7 of development is marked by interstitial tissue growth. At 43 days it occupies almost as much place as the sex cords (fig. 2). However, it is still only constifuted of mesenchymal cells having a mean diameter of $5 \mu$, being widely spaced and possessing long prolongations in contact with those of adjacent cells but having no specialized junctions (fig. 3). The irregularly shaped nucleus contains one or two nucleoli and occupies most of the cell (fig. 3). The reduced cytoplasm has classica equipment : mitochondria with lamellate cristae, Golgi apparatus, two centrioles, one of which sometimes forms a cilium, an exclusively rough endoplasmic reticulum (RER) formed of a small number of cisternae, ribosomes and free polysomes as well as microtubules and filaments.

The Leydig cells differentiate during week 8 of development. From 49 to 51 days, some cells assume a polygonal shape with a denser cytoplasm (figs. 4,5 ). Their shorter prolongations establish desmosome-like junctions with similar neighboring cells (fig. 6) or those still mesenchymal (fig. 7). The nucleus becomes spheric with more voluminous nucleoli presenting evident signs of activity, i. e. granular nucleolonema developed, large fibrillary zones (figs. 5,6). The chromatin is more finely distributed (fig. 6) and perichromatinian granules may be observed. The rough endoplasmic reticulum (RER) develops in several days many small smooth cisternae and patches of anastomosed tubes and vesicles (SER) (fig. 6). The cytoplasm of some cells contains lipid droplets (fig. 6) and the mitochondria, still few in number, begin to form tubular cristae.

It should be noted that Leydig cell differentiation is not synchronous so that the interstitial cell population appears very heterogeneous during week 8 of development. However, at 51 days, the Leydig cells, isolated or in groups of 2 or 3, are well into the process of differentiation (fig. 6). At 53 days the Leydig cell groups are large and numerous, representing 30 to $40 \mathrm{p}$. 100 of the interstitial cells. The junction surfaces are more extensive (fig. 7). The SER, mainly tubular and vesicular, occupies a larger space while the RER does not develop (figs. 7, 8). The SER tubes sometimes form complex anastomosed networks (fig. 8) and primary figures of fenestrated lamellae appear (fig. 9). Originally randomly distributed, mitochondria tend to regroup in SER areas and some are closely joined to smooth cisternae (fig. 10). Their structure does not change during subsequent development, the cristae being fubular and lamellate. These young Leydig cells and later ones are equipped with free polysomes, microtubules, filaments and cilia similar to those found in the mesenchymal cells from which they derive. On the other hand, the Golgi apparatus, in which the dictyosomes remain

\section{PLATE I]}

FIG. 4. - Very young Leydig cells (arrows) begin to emerge in a 50-day testis. $\times 2500$.

FIG. 5. - Typical young Leydig cells already present (arrows) in a 51-day testis, and a typical germ cell (gc) in a sex cord. $\times 2500$. 


\section{PLATE III}

FIG. 6. - 3 Leydig cells in a 51-day testis showing SER areas ( $(7)$ lipid droplets (li) and junctions (arrows). $\times 10000$.

FIGS. 7, 8, 9, 10, - Leydig cells in a 53-day testis. 7 : tubulo-vesicular SER ( $($ ) junctions (arrows). $\times 10000 ; 8$ : anastomosed SER $(*), \times 15000$; 9 : packed fenestrated SER lamellae $(*)$, dictyosome (d) and lysosome (ly), $\times 12500 ; 10$ : smooth cisternae (arrows) along mitochondria with some tubular cristae. Note the circular profile of a cup-shaped mitochondrion, including a rough cisterna whose mitochondrial face is devoid of ribosomes $(\rightarrow \leftarrow) \times 30000$. 
small ( 0.5 to $0.8 \mu$ in diameter), forms a variety of dense vesicles assimilable to lysosomes (fig. 9).

At 57 to 66 days, the volume occupied by the interstitial tissue becomes larger than that of the sex cords (60 as against 40 p. 100). The Leydig cells are large $(10$ to $15 \mu$ in diameter) and grouped into bigger islets (figs. 11,12); they constitute more than one-half of the interstitial cell population. The rest is composed of mesenchymal cells and a fibroblast layer surrounding the sex cords. Thus, for about 10 days, the Leydig cells are in the maturity stage. They are relatively homogeneous, their structural organization having attained its maximum specificity. Junction surfaces are extensive and diversified (zonula adhaerens, gap and tight junctions) ; interdigitations are very frequent (fig. 11). The SER is constituted of long flexuose cisternae moving between the mitochondria and regrouping in vast fenestrated or unfenestrated lamellate piles at the cell periphery (figs. 11,13,14). Mitochondria are now very numerous; the number of lipid droplets remains stationary. Most of the cytoplasm is occupied by SER-mitochondrion-lipid droplet association (figs. 11, 13). The RER usually only forms small islets of parallel cisternae inserted between those of the SER, thus forming a vast continuous network (fig. 13).

After 66 days and up to 82 days, the relative volume of interstitial cell tissue decreases to become equal to that of the sex cords and the number of Leydig cells decreases progressively. They represent less than one half of the cell population of the interstifum at 71 days and less than 10 p. 100 at 82 days. The mesenchymal cells elongate to form several fibroblastic layers around the sex cords (figs. 15, 16,17). The decrease in Leydig cell number during this period of involution is also accompanied by a modification in the organization of these cells, although all are not involved at the same time. Most become smaller and elongate (figs. 16,17), perhaps because the sex cords grow slowly, occupying more place. However, the SER is less developed, i. e. vast lamellate piles are rare (fig. 18), while tubes and vesicles predominate (fig. 20) as at the onset of differentiation. The cytoplasm is particularly dense with lipid inclusion and rich in mitochondria (fig. 18) between which thin SER cisternae still move (fig. 20).

In summary, the Leydig cell population regresses and again becomes heterogeneous during the involution phase. These cells are usually less differentiated and some show evident signs of degeneration, particularly vacuolization of the endoplasmic reticulum and mitochondria (fig. 19). Moreover, many exiravascular leucocytes are seen in the festicular interstitial tissue at 82 days.

PLATE IV

FIG. 11. - 57-day testis. Note extensive junctions between 3 Leydig cells ( $*$ ) and large SER areas (arrows). Germ cell (gc) in a sex cord. $\times 6000$.

FIG. 12. - Large islets of Leydig cells surrounding sex cords (sc) near the funica albuginea (a) of a 66-day testis $\times 250$. 
PLATE V

FIGS. 13, 14. - Mature Leydig cells in a 62-day testis $\times 30000.13$ : note typical SER-mitochondrionlipid droplet association, continuity between RER and SER, free ribosomes in the hyaloplasm, small dictyosome (d) and a section of an inferdigifation between 2 Leydig cells joined by a gap junction ( $¥$ ). A cilium (ci) in a neighboring mensenchymal cell. 14 : large pile of SER cisternae. 


\section{Discussion.}

In Macaca mulatta, differentiated testes are clearly visible at the histological level at days 40 to 42 of fetal development and the first Leydig cells at 54 to 55 days (Wagenen and Simpson, 1965). If testis differentiation (39 to 40 days) and that of the Leydig cells ( 50 to 51 days) seem earlier in $M$. fascicularis, it is probably due to a more refined analysis at ultrastructural level. It is therefore very probable that the chronology of testis developmental stages is the same in these two close species.

The differentiation and regression of interstitial tissue in $M$. fascicularis are very similar to those described in man (Pelliniemi and Niemi, 1969), but they last a shorter time in reference to the length of fetal development. Four phases have been easily recognized in man : predifferentiation, differentiation, maturity and involution. Based on the same ultrastructural criteria and density of Leydig cell population, the same stages have been observed in macaque (table 1).

TABLE 1

Comparative chronology of fetal leydig cell evolution in man and macaque

\begin{tabular}{|c|c|c|c|c|}
\hline & & \multicolumn{2}{|c|}{ Man } & 1. fascicularis \\
\hline $\begin{array}{l}\text { Leydig cells } \\
\text { Lenght of pr }\end{array}$ & $\begin{array}{l}\text { Predifferentiation } \\
\text { Differentiation } \\
\text { Maturity } \\
\text { Involution } \\
\text { egnancy }\end{array}$ & $\begin{array}{l}\text { Before } 8 \text { weeks } \\
8-14 \text { weeks } \\
14-18 \text { weeks } \\
18-40 \text { weeks } \\
40 \text { weeks }\end{array}$ & 10-11 weeks & $\begin{array}{l}\text { week } 7 \\
\text { week } 8 \\
\text { week } 9 \text { ( } 57-66 \text { days) } \\
\text { week } 10-11 \\
24 \text { weeks }\end{array}$ \\
\hline
\end{tabular}

The phase of differentiation is especially sudden in the macaque. On the other hand, the relative length of the maturity phase is comparable to that of man. The early fetal involution phase is perhaps particular to primates because in most other species studied (rat : Narbaitz and Adler, 1967 ; mouse : Scheib, 1972 ; hamster : Gondos ef al., 1974 ; pig : Meusy-Dessolle, 1972) it is post-natal, and has not been observed in guinea-pig (Black and Christensen, 1969).

A general pattern is clearly found in the structural differentiation of Leydig cells. In all cases studied (see references in Introduction), overall cell growth (nucleus

\section{PLATE VI}

FIG. 15. - 71-day testis $\times 250$. Fig. $16: 78$-day festis $\times 3000$. Fig. $17: 82$-day testis $\times 250$. During the first 2 weeks of the involution period, the number and size of Leydig cells (arrows) diminish dramatically. 
and cytoplasm) occurs first. The SER then develops from the RER which shows little extension. The mitochondria multiply and form more or less numerous tubular cristae. Lipid inclusions accumulate in mitochondrion-rich SER areas.

Naturally, there are specific diffrernces; the degree of SER extension and the presence of lamellate piles may show species variation. They are very developed in guinea-pig (Black and Christensen, 1969), rat (Narbaitz and Adler, 1967), man (Pelliniemi and Niemi, 1969) and pig (Meusy-Dessolle, 1972), but not in mouse (Scheib, 1972) or hamster (Gondos et al., 1974). The importance of Leydig cell junctions has only rarely been emphasized (guinea-pig, pig), although they may morphologically indicate a cell recruitment process during differentiation. The fact that mitochondrial and cytoplasmic inclusions are present in some species and not in others is difficult to interprete, as well as the variable frequency of cilia.

It has been known for some time (Christensen and Gillim, 1969 ; Christensen, 1975) that Leydig cell SER participates in endogenous cholesterol synthesis and that the mitochondria convert it into pregnenolone which is taken up by the SER for testosterone synthesis. It is also known that lipid inclusions do not contain steroids but only cholesterol and other precursors. Thus, SER development, multiplication of characteristic mitochondria with tubular cristae, their close association in large operational areas and lipid accumulation are also specific signs of Leydig cell steroidogenic differentiation.

The chronology of Leydig cell structural differentiation in the $M$. fascicularis fetus may thus be related to the ability of those cells to synthesize testosterone and other androgens. Androgens can probably be defected at 50 to 51 days when the structures necessary for their synthesis have developed. Unfortunately, we were unable to determine plasma testosterone levels before 57 days because blood sampling was too random. The maturity stage would correspond to a maximum aptitude of the testis for synthesis during the next 10 days. During this period, the Leydig cell population density is higher, stable and relatively homogeneous. The SER is then at maximum extension with many associated mitochondria in operational areas, while the quantity of lipid droplets no longer increases since the end of differentiation.

During the involution phase (after 66 days), Leydig cells are scattered in the interstitial tissue, both because new cells are no longer recruited and also because older ones degenerate. Some of them resemble those observed during differentation : reduced SER, fragmented into tubes and vesicles. This aspect suggests a dedifferentiation, although the mitocondria remain abundant and the relationship with SER is often preserved. It is probable that only SER reduction is sufficient to decrease andro-

\section{PLATE VII}

FIG. 18. - 71-day testis $\times 6000$. In most Leydig cells SER is considerably reduced, whereas lipid droplets accumulate. Fig. 19 : Degenerescent Leydig cells (arrow) among intact cells $\times 5000$. Fig. 20 : Continuities between tubulo-vesicular SER and RER, free ribosomes and junction (arrow) in a Leydig cell at 78 days $\times 24400$. 
gen-synthesizing ability, thus causing increased accumulation of lipid droplets corresponding to the immobilization of previously synthesized precursors.

This interpretation of steroidogenic activity of Leydig cells is supported by our results on plasma testosterone levels in the same fetuses. In male fetuses, a mean testosterone level of $2.28 \pm 0.47 \mathrm{ng} / \mathrm{ml}$ was found in 4 fetuses aged 57 to 66 days, and a mean level of $1.69 \pm 0.66 \mathrm{ng} / \mathrm{ml}$ in 3 fetuses aged 71 to 82 days. On the other hand, in female fetuses, testosterone levels were much lower and practically constant during the periods studied : $0.34 \pm 0.06 \mathrm{ng} / \mathrm{ml}$ between 58 and 66 days ( 4 fetuses) and $0.42 \pm 0.10 \mathrm{ng} / \mathrm{ml}$ between 67 and 84 days (4 fetuses). It is interesting to note that plasma testosterone levels in male and female Macaca fasicularis are very silmilar to those measured in Macaca mulatta during the same developmental periods (Resko ef al., 1973).

Reçu en février 1978.

Accepté en mai 1978.

Acknowledgments. - The authors wish to thank Professor C. Thibault for helpful discussion and criticism of the manuscript, Professor R. Weill for the opportunity to use the JEM, Mrs. D. Genotelle-Septier for electron microscope assistance and Mrs. A. Daifuku for translation of the manuscript. This work was supported by the DGRST, Grant No 77.7.0671.

Résumé. Le tissu interstitiel testiculaire de Macaca fascicularis a été éfudié par microscopie électronique chez 22 fœtus âgés de 37 à 82 jours. Le testicule se différencie au cours de la $6^{\mathrm{e}}$ semaine de gestation. Le tissu interstitiel n'est composé que de cellules mésenchymateuses pendant la $7 \mathrm{e}$ semaine (phase de prédifférenciation). Les cellules de Leydig typiques entrent en phase de différenciation pendant la $8^{\mathrm{e}}$ semaine, formant progressivement une population dense et relativement homogène. Cet état maximum de développement se maintient pendant les 10 jours suivants (phase de mafurité). Les cellules de Leydig entrent en phase d'involution dès la fin de la $10^{\mathrm{e}}$ semaine, la plupart se dédifférencient et certaines dégénèrent. Cette chronologie en 4 phases est comparable à celle décrife chez l'Homme.

La différenciation ultrastructurale des cellules de Leydig du Macaque obéit au schéma général observé chez d'autres espèces : développement du SER, multiplication de mifochondries à crêtes tubulaires et accumulation de gouttes lipidiques. Ces structures sont associées en territoires opérationnels dont l'extension est maximale pendant la phase de maturité. Plus tard, le SER régresse et les gouttes lipidiques sont plus nombreuses. Une bonne corrélation est observée entre le développement structural des cellules de Leydig ef la testostéronémie des mêmes fœetus.

\section{References}

BLACK V. H., CHRISTENSEN A. K., 1969. Differentiation of interstitial cells and Sertoli cells in fetal Guinea pig testes. Am. J. Anat., 124, 211-238.

CHRISTENSEN A. K., 1975. Leydig cells. In HAMILTON D. W., GREEP R. O., Handbook of Physiology, Male reproductive system, vol. 5, sect. 7, Chap. 3, 57-94. Amer. Physiol. Soc., Washington.

CHRISTENSEN A. K., GILLIM S. W., 1969. The correlation of fine structure and function in steroid secreting cells with emphasis on those of gonads, 415-488. In Mc KERNS K. W., The Gonads, Appleton Century Crofts, New York.

DANG D. C., 1977a. Absence of seasonal variation in the length of the menstrual cycle and the fertility of the crab-eating macaque (Macaca fascicularis) raised under natural daylight ratio. Ann. Biol. anim. Bioch. Biophys., 17, 1-7. 
DANG D. C., 1977b. Resumption of menstruation and fertility after cesarian in Macaca fascicularis. Ann. Biol. anim. Bioch. Biophys., 17, 325-329.

GONDOS B., CONNER L. A., 1972. Ultrastructural differentiation of interstitial cells in the fetal and postnatal rabbit testis. Biol. Reprod., 7, 118 (abstr.).

GONDOS B., PAUP D. C., ROSS J., GORSKI R. A., 1974. Ultrastructural differentiation of Leydig cells in the fetal and postnatal hamster testis. Anat. Rec., 178, 551-566.

JOST A., VIGIER B., PREPIN J., PERCHELLET J.-P., 1973. Studies on sex differentiation in mammals. In Recent Progr. Hormone Rese., 29, 1-41. Acad. Press, New York, London,

LUFT J. H., 1961. Improvements in epoxy resin embedding methods. J. biophys. biochem. Cytol., 9, 409-414.

MERCHANT-LARIOS H., 1976. The onset of testicular differentiation in the rat : an ultrastructural study. Am. J. Anat., 145, 319-330.

MEUSY-DESSOLLE N., 1972. La cellule interstitielle tesficulaire des mammifères, 19-72. In THIBAULT C., Fécondité et stérilité du mâle, acquisitions récentes. Masson, Paris.

MEUSY-DESSOLLE N., 1974. Evolution du taux de festostérone plasmatique au cours de la vie fœitale chez le porc domestique (Sus scrofa L.). C. R. Acad. Sci., Paris Série D, 278, 1257-1260.

NARBAITZ R., ADLER R., 1967. Submicroscopical aspects in differentiation of rat fetal interstitial cells. Acta physiol. lat. amer., 17, 286-291.

PELLINIEMI L. J., NIEMI M., 1969. Fine structure of the human fœetal testis. I. The interstitial tissue. $Z$. Zellforsch., 99, 507-522.

RESKO J. A., MALLEY A., BEGLEY D., HESS D. L., 1973. Radioimmunoassay of testosterone during fetal development of the Rhesus monkey. Endocrinology, 93, 156-161.

RIGAUDIERE N., 1976. Teneurs en testostérone et en dihydrotestostérone du testicule au cours du développement embryonnaire chez le cobaye. C. R. Soc. Biol., 170, 772-778.

RUSSO J., DE ROSAS J. C., 1971. Differentiation of the Leydig cells of the mouse testis during the fetal periodan ultrastructural study. Am. J. Anat., 130, 461-480.

SCHEIB D., 1972. Ultrastructure et fonction des cellules interstitielles du testicule de la sour is : évolution forale. Ann. Embryol. Morph., 5, 121-133.

VENABLE J. H., COGGESHALL R., 1965. A simplified lead citrate stain for use in electron microscopy. J. Cell Biol., 25, 407-408.

WAGENEN, G. VAN, SIMPSON M. E., 1965. Embryology of the ovary and testis. Homo sapiens and Macaca mulatta. New Haven, U. S. A., Yale University Press. 